\title{
Mauremys reevesii (Gray 1831) - \\ Reeves' Turtle, Chinese Three-Keeled Pond Turtle
}

\author{
JefFrey E. Lovich ${ }^{1}$, Yuichirou Yasukawa ${ }^{2}$, and Hidetoshi Ota ${ }^{3,4}$ \\ ${ }^{1}$ United States Geological Survey, Southwest Biological Science Center, 2255 North Gemini Drive, \\ MS-9394, Flagstaff, Arizona 86001 USA [jeffrey_lovich@usgs.gov]; \\ ${ }^{2}$ District Office Okinawa, Takada Reptiles and Wildlife Research Institute, 1-15-3 Teruya, Okinawa City, \\ Okinawa904-0011Japan [guau_yasukawa@ybb.ne.jp]; \\ ${ }^{3}$ Tropical Biosphere Research Center, University of the Ryukyus, Nishihara-cho, Okinawa 903-0213 Japan; \\ ${ }^{4}$ Present Address: Institute of Natural and Environmental Sciences and Museum of Nature and Human Activities, \\ University of Hyogo,Yayoi-gaoka 6, Sanda, Hyogo 669-1546, Japan [ohta@hitohaku.jp]
}

Summary. - Mauremys reevesii, Reeves' Turtle (or Chinese Three-keeled Pond Turtle) (Family Geoemydidae), is a moderate-sized aquatic species (carapace length to $300 \mathrm{~mm}$ ) widely distributed in East Asia throughout central and eastern continental China, exclusive of the most southern, western, and northern regions, and including Taiwan, southern Japan, and part of the Korean peninsula. However, the native distribution has been extended by human-aided translocations. The turtle lives in freshwater habitats in lowland areas with still or slowly moving water. Although no concrete data are available regarding the status of most populations, it is apparent that most have experienced major declines as a result of habitat destruction and/or commercial over-exploitation. Intentional and accidental releases of specimens from continental Asia may be altering the genetic stock of Japanese populations. Effective conservation of the species will require habitat protection and regulations to control the collection and transportation of wild animals. Additional studies are needed on the status, life history, and demography of the species.

Distribution. - China, Japan (introduced?), North Korea, South Korea, Taiwan (introduced?); introduced in Indonesia, Japan, Palau, Timor-Leste. Native distribution includes most of central and eastern continental China and the Korean peninsula, with populations in Taiwan and southern Japan possibly introduced in prehistoric and historic times.

Synonymy.-Emys reevesii Gray 1831,Clemmys (Clemmys) reevesii, Geoclemys reevesii, Geoclemys reevesii reevesii, Damonia reevesii, Chinemys reevesii, Emys vulgaris picta Schlegel 1844, Emys japonica Duméril and Bibron in Duméril and Duméril 1851, Damonia unicolor Gray 1873, Clemmys unicolor, Damonia reevesii unicolor, Geoclemys reevesii unicolor, Geoclemys grangeri Schmidt 1925, Geoclemys reevesii grangeri, Chinemys grangeri, Geoclemys paracaretta Chang 1929, Chinemys megalocephala Fang 1934, Chinemys pani $\uparrow$ Tao 1985, Mauremys pritchardi McCord 1997 (partim, hybrid).

SubSPECIES. - None.

Status. - IUCN 2011 Red List: Endangered (EN A2bcd+4bcd) (assessed 2011); CITES: Appendix III (China).

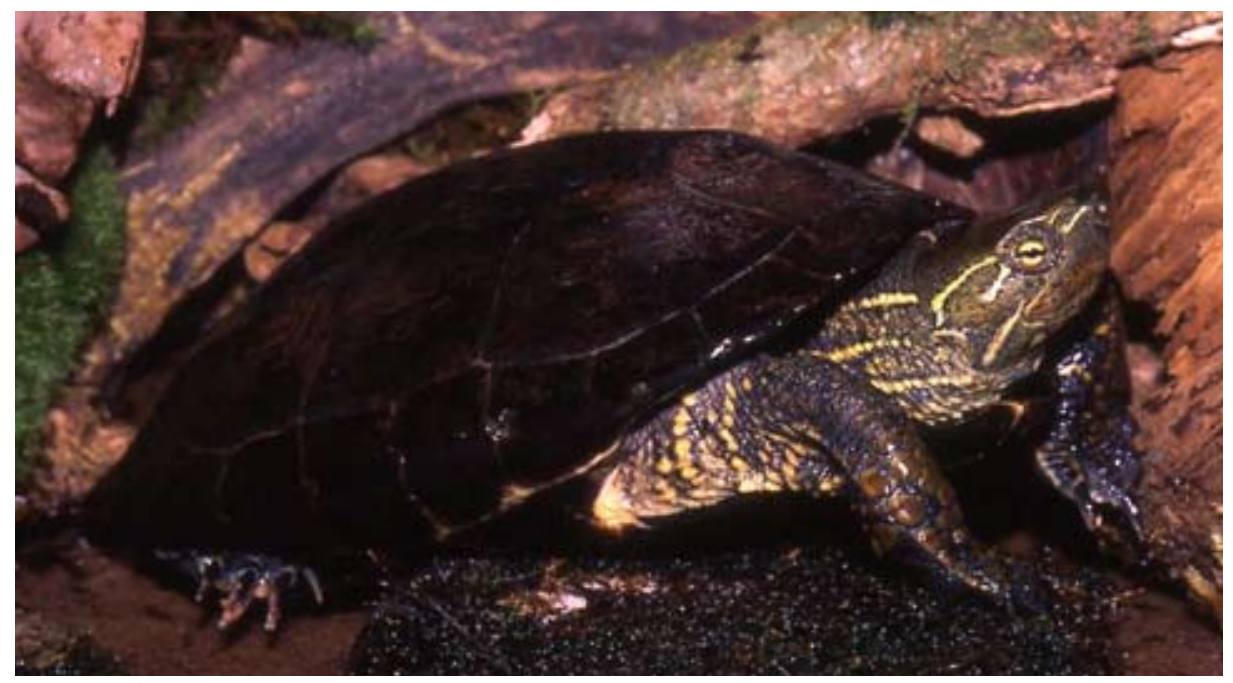

Figure 1. Adult female Mauremys reevesii from Honshu, Japan. Photo by Nobuhiro Kawazoe. 


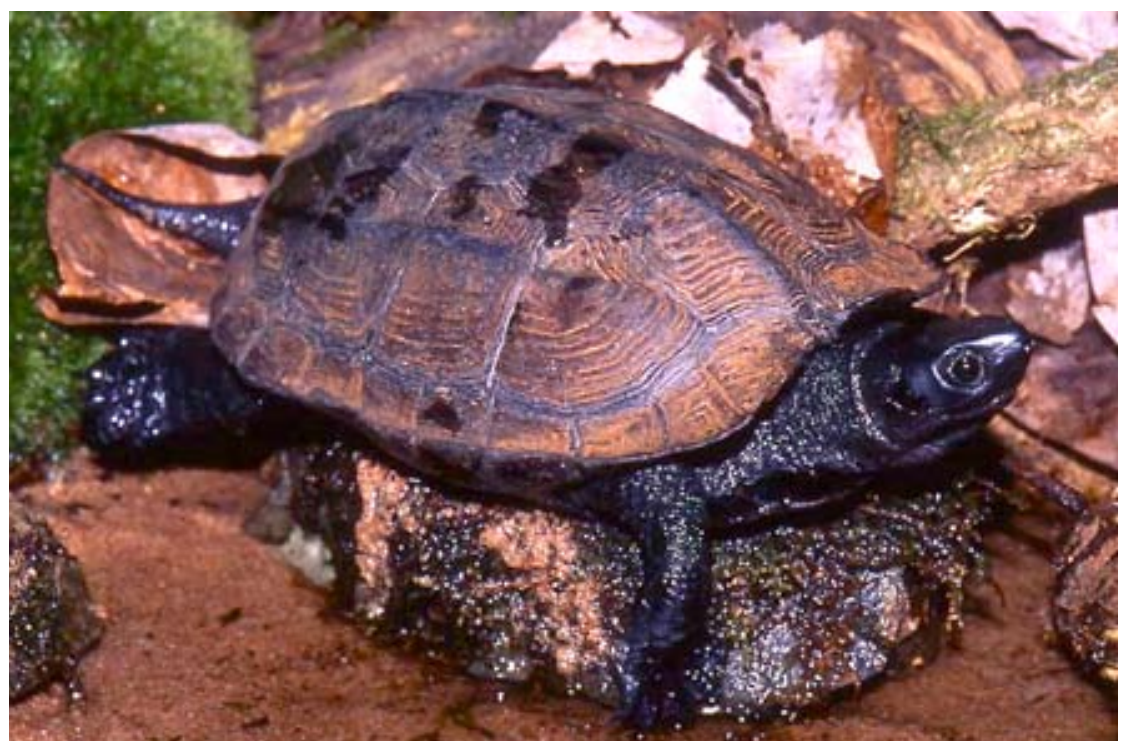

Figure 2. Adult melanistic male Mauremys reevesii from Honshu, Japan. Photo by Nobuhiro Kawazoe.

Taxonomy. - Mauremys reevesii was originally described from China by Gray (1831) as Emys reevesii. Generic allocation of the species was changed several times by subsequent authors. In the latter half of the 20th Century, it was usually regarded as the type species of the valid genus Chinemys Smith 1931 (e.g.,Ernst and Barbour 1989; Iverson 1992; Zhao and Adler 1993), which was assigned to the subfamily Batagurinae (now Geoemydidae) on the basis of cladistic analysis of morphological data (Hirayama 1984; Gaffney and Meylan 1988; Yasukawa et al.2001). However, this view has been challenged by recent phylogenetic studies.

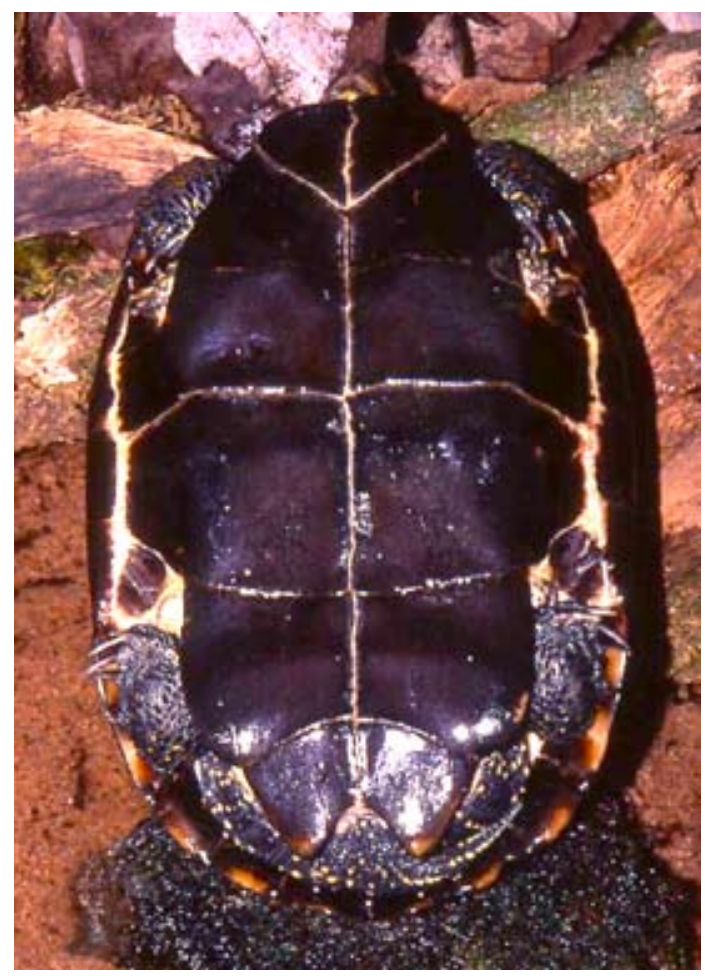

Figure 3. Adult female Mauremys reevesii from Honshu, Japan. Photo by Nobuhiro Kawazoe.
Shaffer et al. (1997) used a combination of molecular and morphological data to suggest a possible close affinity of Chinemys with Heosemys. Moreover, more recent molecular studies have yielded phylogenetic trees on which Chinemys, as well as the genus Ocadia, are consistently located within a cluster with the genus Mauremys (Wu et al. 1998; McCord et al. 2000; Honda et al. 2002; Barth et al. 2004; Spinks et al. 2004; Feldman and Parham 2004; Sasaki et al. 2006; Jiang et al. 2011). In contrast, Parham et al. (2001) presented a phylogenetic hypothesis based on molecular data where $C$. reevesii and $C$. nigricans were clearly separated from Mauremys species recognized at that date. After reviewing these systematic incongruities, Spinks et al.(2004) proposed synonymization of Chinemys and Ocadia with Mauremys, and the Turtle Taxonomy Working Group (2007) placed reevesii, as well as a few other species, long assigned to Chinemys and Ocadia, in the genus Mauremys.

Mauremys reevesii occasionally hybridizes with other geoemydid species such as M.japonica (Kosuge et al. 2003; Kato et al. 2010; Yasukawa and Ota, pers. obs.), and M. sinensis (Fong and Chen 2010; Xia et al. 2011), sometimes leading to confusion in the taxonomy and relationships of this and allied turtles. For example, M. pritchardi, described by McCord in 1997, proved to be a hybrid between M. reevesii

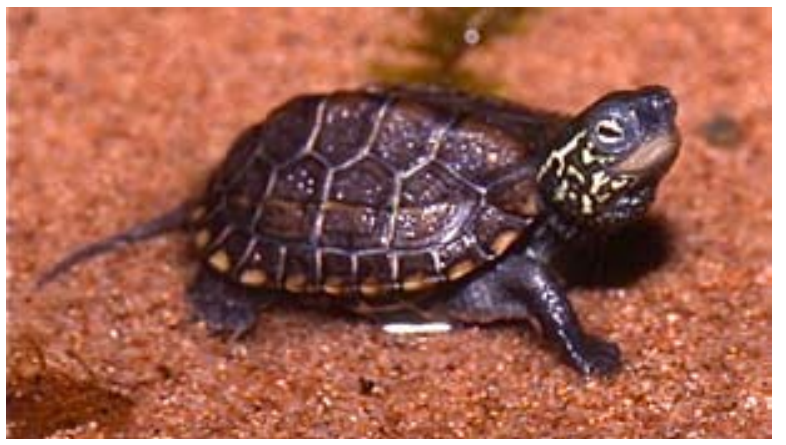

Figure 4. Juvenile Mauremys reevesii from captive breeding in Japan. Photo by Nobuhiro Kawazoe. 


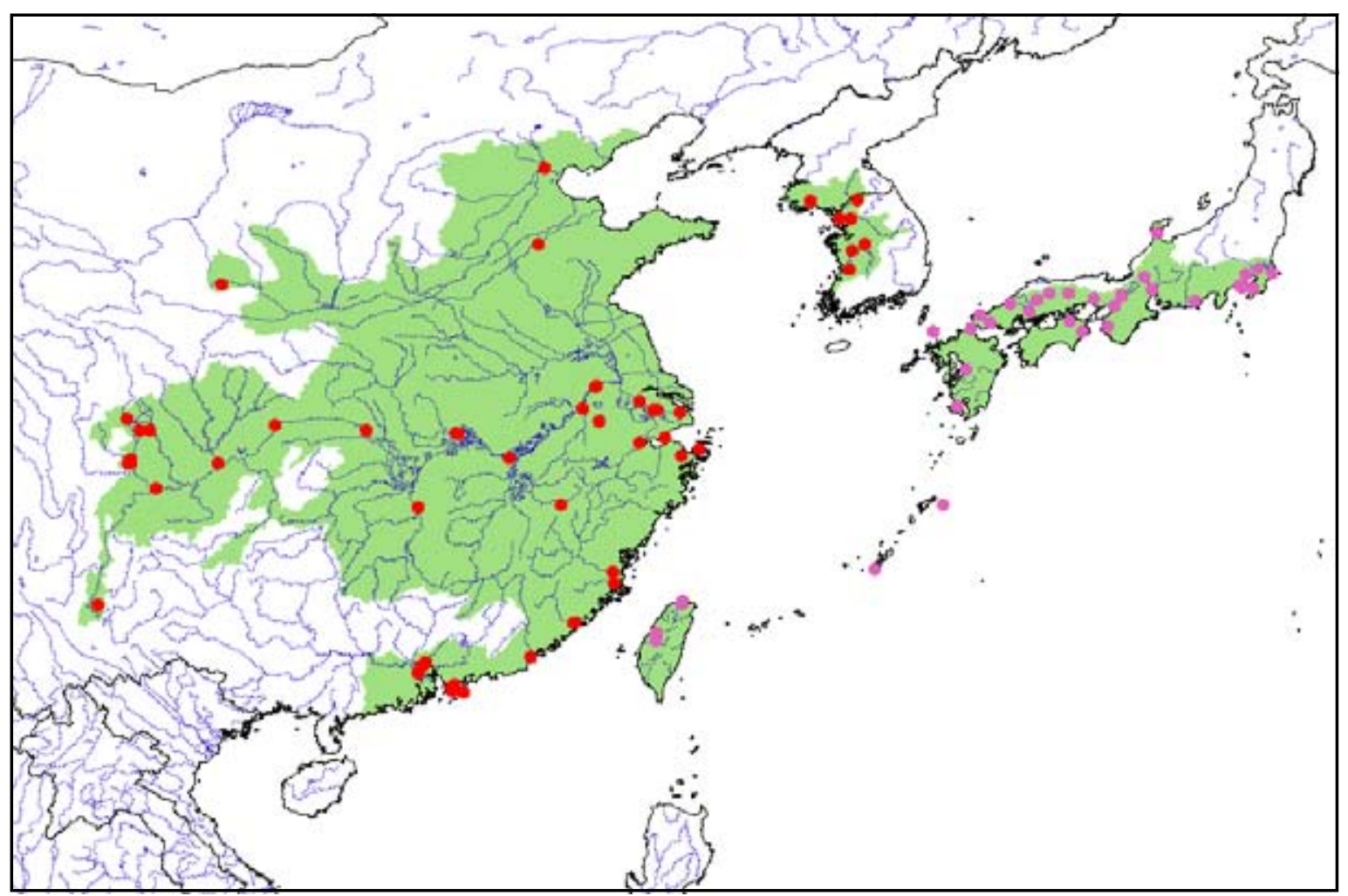

Figure 5. Distribution of Mauremys reevesii in China, North Korea, South Korea, Japan (introduced?), and Taiwan (introduced?). Red dots = museum and literature occurrence records of native populations based on Iverson (1992) plus more recent and authors' data; purple dots $=$ occurrence records of apparently introduced populations; green shading = projected distribution based on GIS-defined hydrologic unit compartments (HUCs) constructed around verified localities and then adding HUCs that connect known point localities in the same watershed or physiographic region, and similar habitats and elevations as verified HUCs (Buhlmann et al. 2009), and adjusted based on authors' data.

and M. mutica (Dalton 2003; Wink et al. 2001; Honda et al. 2007). Likewise, several variants of $M$. reevesii were erroneously described as distinct species (e.g., Damonia unicolor Gray 1873, Geoclemys grangeri Schmidt 1925, and Geoclemys paracaretta Chang 1929). These taxa were placed in the synonymy of M.reevesii by numerous authors as reviewed by Lovich et al. (1985), although Pritchard (1994) subsequently considered G. paracaretta to be synonymous with $M$. nigricans. Iverson et al. (1989) also included $C$. megalocephala Fang 1934 in the synonymy of C. reevesii; an arrangement that was not adopted by Zhao and Adler (1993). Recently Barth et al. (2003, 2004) reported the absence of sequence variation in mitochondrial cytochrome $b$ gene between $M$. reevesii and $C$. megalocephala. Their result supports Iverson et al.'s (1989) synonymy.

No subspecies are currently recognized. After making morphological comparisons among samples from several regions, including mainland Asia, Taiwan, and the JapaneseKorean region, Lovich et al. (1985) concluded that, although the coloration of $M$. reevesii varies to some extent, there is no geographically correlated variation within the species. In Japan, however, individuals belonging to western Honshu populations (Shibata 1967) appear distinct in plastron coloration and morphology compared to those imported from China in the early 1970s that established breeding colonies in eastern Honshu (Aoki 1974, 1990; Yasukawa, pers. obs.). Based on the almost complete absence of old
Japanese literature referring to this species and the absence of Pleistocene-Holocene fossils and sub-fossils in Japan, several recent authors argued for the exotic origin of all current Japanese populations of M. reevesii (Hirayama et al. 2007; Hirayama and Isaji 2010; Hikida and Suzuki 2010). Suzuki et al. (2011) tentatively attributed distinct morphological and mitochondrial haplotype variations observed among Japanese populations to their originating from artificially introduced continental individuals belonging to diverse haplotype lineages. Indeed, genetic diversity in the continent (e.g., Hubei Province, China) is considered to be high (Zhu et al. 2005).

Based on the recent genetic surveys of Mauremys in Taiwan, Fong and Chen (2010) surmised that M. reevesii on this island are also derived from artificial introductions from mainland Asia. Harvesting, commercial trading, and even intentional releases (for religious reasons) of this turtle still happen in China (e.g., Lau and Shi 2000; Shi et al. 2008; Gong et al. 2009). Therefore, additional studies of geographic variation are needed to elucidate differences among local populations before artificial gene flow caused by translocations and introductions completely obfuscates natural patterns.

Description. - Mauremys reevesii is a medium-sized geoemydid turtle attaining a straight line carapace length (CL) of at least $300 \mathrm{~mm}$. The carapace is oval and low-arched, possesses three longitudinal keels that are more-or-less 
parallel to each other, and is not serrated at the posterior margin, even in juveniles. The bridge is long and possesses axillary and inguinal scutes. The plastron is large, elongate, hingeless, and unnotched anteriorly, but deeply notched posteriorly. Variation in plastral formula is extensive as shown by Lovich and Ernst (1989). The entoplastron is intersected by the humeral-pectoral seam but not the gularhumeral seam. Plastron buttresses are well-developed, and firmly connected to the carapace. The head is large, and its dorsal surface is subdivided into small scales. The upper jaw is slightly notched and unhooked medially. Triturating surfaces of the upper and lower jaws are wide, without any ridges, serrations, or cusps. The four limbs have fully webbed digits. Cloacal bursae are well-developed.

The skull of $M$. reevesii is massive and wide. The anterior end of the processus inferior parietalis is in contact with the palatine, jugal, pterygoid, and quadratojugal bones, but is separated from the maxilla by the palatines. The foramen nervi vidiani is lost. The jugal, postorbital, and quadratojugal are connected with each other, forming a well-developed temporal arch. The postorbital does not usually contact the squamosal and quadrate. The fissure ethmoidalis is narrow and keyhole-shaped.

In non-melanistic individuals, the carapace is light to dark brown, sometimes with broken stripes along the longitudinal keels. The carapace of hatchlings is usually more light-colored, especially around its outer margin. The coloration of the plastron is highly variable, from uniform dark brown to horn-colored with a smear of darker pigments (Sachsse 1975a; Lovich et al. 1990). Most specimens have dark blotches in the center of each plastral scute, some with radiating lines on the periphery. The ground color of the head and throat varies from grayish to dark brown. Lateral surfaces of the head and neck possess a series of broken yellowish stripes extending from the snout (sometimes from the posterior margin of the orbit). The limbs and tail are brown or dark gray, but irregular light spots are sometimes scattered on the basal portions of limbs. Adult male M. reevesii tend to become melanistic as they grow older and larger, and large males occasionally lose all light markings on the shell and soft parts. Females do not exhibit this trend in coloration (Mao 1971; Sachsse 1975a; Sengoku 1979; Lovich et al. 1990; Yabe 1994). Yabe (1994) reported an extreme case of male melanism in a central Honshu population, in which males, including an individual of $120 \mathrm{~mm} \mathrm{CL}$ and all those greater than $145 \mathrm{~mm}$ CL, lost all light markings. He assumed that the degree of the melanistic change in this species is correlated more with body size than with age. Later, he reported regional variation in male size at which melanism starts, with eastern Honshu males tending to become melanistic at a smaller CL size (Yabe 2009). Melanistic males from Japan also exhibit changes in iris color and characteristics of the liver and fat, relative to non-melanistic males (Yasukawa, pers.obs.).

Pritchard $(1979,1994)$ suggested that Japanese $M$. reevesii may attain greater carapace lengths than Chinese populations. The largest specimen examined by Lovich et al.
(1985), a female measuring $236 \mathrm{~mm} \mathrm{CL}$, was from Szechwan Province, China (Ernst and Barbour 1989), whereas Aoki (1990) mentioned a gigantic female from Japan with a carapace measuring $355 \mathrm{~mm}$ in length. Although this latter value was actually for curved CL, the straightline CL greatly exceeded $300 \mathrm{~mm}$ (R. Aoki, pers. comm.). This figure is much larger than those reviewed by Pritchard (1994) for the record size of $M$. reevesii, including the megalocephalic form (previously recognized as $C$. megalocephala: Iverson et al. 1989). Males are much smaller than females, attaining a CL of $200 \mathrm{~mm}$ at most (Yabe 1994; Yasukawa,pers. obs.). Yabe (1994) reported on a population in Gifu Prefecture, Japan, in which adult females and males exhibited a modal CL of $185-195 \mathrm{~mm}(\max 237.0 \mathrm{~mm})$ and $145-155 \mathrm{~mm}(\max 185.3$ $\mathrm{mm})$, respectively.

Mauremys reevesii shows distinct sexual dimorphism (Mao 1971; Gibbons and Lovich 1990). Males have a lower and narrower carapace, a shorter and narrower plastron, and shorter bridges compared to females. The plastron is flat in females and slightly concave in males. In males the tail is long and thick, with the vent located beyond the posterior rim of the carapace. Du and Shen (2007) reported that in body mass males and females are similar for the first three months after hatching, but then females grow much faster than males, leading to female-biased sexual size dimorphism.

The karyotype of $M$. reevesii consists of $2 n=52$ chromosomes, including nine pairs of metacentric or submetacentric macrochromosomes, five pairs of telocentric or subtelocentric chromosomes, and 12 pairs of microchromosomes (Bickham and Carr 1983; Kojima and Yamamoto-Yamazaki 1987).

Distribution. - Mauremys reevesii is widely distributed in eastern Asia, including central and eastern continental China, Taiwan, Kimmen Island, southern and central Japan, and Korea (Ota 1991; Szyndlar 1991; Iverson 1992). In Japan, this species occurs in Honshu, Shikoku, and Kyushu on the main islands, as well as on several adjacent small islands such as Sadogashima, Awajishima, Ikijima, Mishima, and Tsushima, and the Okinoshima Group (Ohno 1968; Sengoku 1979; Ota 2001, Yasukawa, pers. obs.); all these may have originated as introductions from mainland Asia before (western Japan) or after World War II (eastern Japan) (Shibata 1967; Aoki 1974, 1990; Hikida and Suzuki 2010; Suzuki et al. 2011: see above). This species was more recently introduced to Kikaijima Island of the Amami Group, and Okinawajima and Kumejima islands of the Okinawa Group, central Ryukyus (Masuno et al. 1998; Okada and Ota 2003; Maenosono and Toda 2007), as well as to Hokkaido in northern Japan (Ota 2001). Also, turtles recorded from Taiwan may be nonnative as well (Fong and Chen 2010: see above).

Zhao and Adler(1993) stated that this species is currently distributed throughout China exclusive of the western and northern regions. However, Pope (1935) assumed that the probable native distribution of this species within China was confined to the Yangtze River Valley from the junction of the Min River eastward and along the coast from Kiangsu to Kwangtung. Thus, the apparent wide range of this turtle in China, as well as in Japan, may be partially attributable to 
artificial translocations (see below), a situation that is likely mirrored by Cuora flavomarginata in China (Fong et al. 2002: but see Ernst and Lovich 1990 and Ernst et al. 2008 for details on range-wide variation in C. flavomarginata). Records from the Philippines and Russia are considered to be extralimital (Ernst and Barbour 1989). This species has also been introduced into Canada and the United States (Cooper 1961; Iverson 1992), Palau (Crombie and Pregill 1999), and Timor-Leste (Kaiser et al. 2010), although breeding populations have not been reported in those countries.

Early Pleistocene remains of $M$. reevesii have been reported from Hsiatsaohwan, in the Shihhung district of northern Anhwei (Chow 1955). A fossil specimen of the Late Pleistocene age was dredged up from a depth of 150-200 $\mathrm{m}$ in the Taiwan Strait near Penghu Island (Tao 1988). Tao (1985) also described Chinemys pani from fossils that she considered to be similar to $M$. reevesii, and the two taxa are often synonymized. Differences between Chinemys pani and $M$.reevesii include an abdominal scute that is shorter than the femoral scute and a wider body in the former. Other minor differences in the size relationships between scutes invite caution in recognizing Chinemys pani as separate from $M$. reevesii given the high degree of variation in plastron scute length relationships in M. reevesii (Lovich and Ernst 1989). No fossil specimens of $M$. reevesii are known from Japan, and some Japanese authors have therefore suspected that the current Japan mainland populations of $M$. reevesii were introduced (Hirayama et al. 2007).

Habitat and Ecology. - Little information is available regarding the habitat and ecology of $M$.reevesii. The species is closely associated with aquatic habitats, inhabiting still or slow moving freshwaters such as the middle and lower reaches of rivers, lakes, ponds, swamps, marshes, and irrigated rice paddies. Proof of its aquatic proclivities is shown by the frequent presence of filamentous green algae on the carapace; a condition that has generated the colloquial name "green-haired turtle" (Pope 1935). In Japan, M. reevesii and the Japanese pond turtle (M.japonica) are frequently found in sympatry in the lowlands, but the former seems to prefer more open habitat compared to the latter, and is rarely found in semi-montane environments (Yabe 1993,2006; Nakajima et al. 2000; Kosuge et al. 2003). This sympatry results in hybridization between $M$.reevesii and $M$.japonica throughout the Koito River in central Japan, even though the former is only found in the lower part of the river basin (Kosuge et al. 2003). Mauremys reevesii is chiefly diurnal, and fond of basking.

Few data are available on the population structure of M. reevesii. Takenaka and Hasegawa (2001) estimated a population of 1179 turtles (1123 individuals captured) in 15 ha of aquatic habitats on Ishima Island, a small island (190 ha) in Japan. Of the turtles captured, 833 were males, 214 were females, and 76 were juveniles or of undetermined sex. Mean carapace length and weight of old individuals whose age was unknown were $131.9 \mathrm{~mm}$ and $353.1 \mathrm{~g}$ in males, and $165.5 \mathrm{~mm}$ and $743.3 \mathrm{~g}$ in females. The sex ratio was basically $1: 1$ in the $3-6$ yr age classes, but significantly biased toward males in the $12 \mathrm{yr}$ and older age classes. A significant female bias was noted in turtles that were found dead (26 of 31 carcasses), suggesting that differential mortality contributed to the male-biased sex ratio observed in the living population. Most of the carcasses were larger than the minimum size of mature females and they were found in areas frequented as hibernacula, suggesting mortality during overwintering.

Mauremys reevesii is omnivorous and feeds on various plants and live and dead animals. One and two year old juveniles stop feeding when ambient temperatures are below $15^{\circ} \mathrm{C}$. Growth rate and average daily food intake are positively correlated with temperature, while passage time was negatively correlated, all as expected for an ectotherm (You et al. 1993). Food items include algae, aquatic macrophytes, fallen fruits, earthworms, aquatic and terrestrial insects, aquatic and terrestrial snails, crayfish, shrimp, crabs, fish, tadpoles, and frogs (Fukada 1965; Sengoku 1979; Noda and Kamata 2004; Yabe and Yasukawa,pers.obs.). The wide triturating surfaces and well-developed masticatory muscles are probably adaptations for feeding on animals with hard shells, such as mollusks and crustaceans. However, the bite force for $M$. reevesii is relatively modest compared to other turtle species (Herrel et al. 2002).

Courtship behavior of $M$. reevesii involves movements by the male to gain a position whereby he can rub his snout or forelimbs against those of the female (Pope 1935; Yasukawa, pers. obs.). Based on captive observations in outdoor enclosures in Japan, Fukada (1965) surmised that mating season begins in early spring, but in captivity courtship behavior is also observed in autumn (Yasukawa, pers. obs.). In Japan, the egg-laying season of $M$. reevesii is usually from June to July (Fukada 1965). In outdoor captivity, nesting has been observed from 6 June to 7 August. Yabe (1994) reported that the smallest egg-bearing female in a natural population was $173 \mathrm{~mm} \mathrm{CL}$, and that clutch size, positively correlated with female CL, ranged from 4-13 (8.3 on average).

Based on observations of individuals kept in outdoor enclosures in Kyoto, Japan, Ishihara (1986) reported that females start to lay eggs at 9-12 yrs of age, and that the smallest egg-laying female measured $149.6 \mathrm{~mm} \mathrm{CL}$. The annual number of clutches ranged from 1-3 and clutch size ranged from 1-14 (7.7 on average). When two clutches are produced the internesting interval is about one month. Nests are constructed with the hind limbs. The nest dug by one female $(175 \mathrm{~mm} \mathrm{CL})$ was $8 \times 7 \mathrm{~cm}$ in diameter $\mathrm{x}$ depth and contained 6 eggs. Another female (172 mm CL) dug a nest that was $10 \times 10 \mathrm{~cm}$ that also contained 6 eggs; mean egg size was $38 \times 22.5 \mathrm{~mm}$ and mean mass $11 \mathrm{~g}$. Some hatchlings emerge from the nest in October, but most overwinter until April or May of the following year. The newly emerged hatchlings have a CL between 24.6-36.6 mm, weigh ca. 6 $\mathrm{g}$, and look like miniature adults with long tails and large heads (Fukada, 1965; Fukada and Ishihara 1974).

Saka et al. (2011) examined seasonal variation in serum vitellogenin (VTG) levels and its relationship to the gonadal cycle in female $M$. reevesii from Kyoto. Two peaks were 
recognized for VTG levels: one in late spring, apparently corresponding to rapid acceleration of vitellogenesis, and the other occurring in autumn, supposedly corresponding to a gradual enlargement of ovarian follicles in preparation for initial ovulation the following spring.

Wang etal.(1995) reported that the lengths of incubation periods (days) in eggs of a continental sample were 66.91 $\pm 3.70,62.29 \pm 9.00$, and $56.57 \pm 2.85$ days at 28,30 , and $33^{\circ} \mathrm{C}$, respectively. They also reported that the masses of hatchlings from incubation at those temperatures averaged $4.83,4.66$, and $4.12 \mathrm{~g}$, respectively. Other authors tested the effects of different moisture levels on incubation (Du and Zheng 2004). At $30^{\circ} \mathrm{C}$, incubation time is just over 60 days on both wet $(-12 \mathrm{kPa})$ and dry $(-300 \mathrm{kPa})$ substrates, although hatchling success rates were $69.2 \%$ and $88.0 \%$, respectively. Wet body mass and carapace width are greater for hatchlings on wet substrates, but dry body mass, carapace length, tail length, limb length, measures of hatchling components (e.g., residual yolk and fat body mass), swimming performance, and critical thermal maxima, were similar between the two water potentials (Du and Zheng 2004). Hatchlings from eggs incubated at 27 and $30^{\circ} \mathrm{C}$ crawled and swam faster than hatchlings incubated at 24 and $33^{\circ} \mathrm{C}$. The critical thermal minima for hatchlings incubated at 30 and $33^{\circ} \mathrm{C}$ were higher than those for hatchlings incubated at 24 and $27^{\circ} \mathrm{C}$ (Du et al. 2006). Du et al. (2007) found that hatchlings from eggs incubated at 24,26 , and $28^{\circ} \mathrm{C}$ are larger and have greater mass than those incubated at 30,32 , and $34^{\circ} \mathrm{C}$. However, eggs incubated at the two high temperature regimes had lower hatching success. By an age of 3 months, the size superiority displayed by hatchlings from lower incubation temperatures disappeared. After 3 months, females from $28^{\circ} \mathrm{C}$ incubation temperatures grew faster than males from the same temperature. The authors concluded that the differences in growth rates were attributable more to between-sex differences rather than temperature effects.

Mauremys reevesii exhibits temperature-dependent sex determination. On the basis of laboratory experiments, Ling (1985) reported that an incubation temperature of $32^{\circ} \mathrm{C}$ produced only females, whereas those ranging between $23-27^{\circ} \mathrm{C}$ produced males. Similar results were reported by Ishihara (1989), Du et al. (2007), and Li and Cui (2011). Based on observations in an outdoor terrarium in Kyoto, Ishihara (1985) reported that eggs laid from 28 May to 2 July (nest temperatures $23.7-28.3^{\circ} \mathrm{C}$ ) produced only males, whereas $78.8 \%$ of eggs laid after 7 July (nest temperatures $26.5-28.7^{\circ} \mathrm{C}$ ) produced females.

In a Chinese population of $M$. reevesii, growth was rapid and relatively constant during the first five years, and then slowed dramatically after the sixth year at which point sexual maturity is probably attained (Liu and Hu 1940). In contrast, rapid growth seems to continue until about ten years after hatching in Japanese populations (Ishihara 1986; Yasukawa,pers.obs.). The smallest male from Japan that had well-developed gonads measured $132 \mathrm{~mm}$ CL (Yasukawa, pers. obs.). Captives have lived for over 24 years (Snider and Bowler 1992).
The Japanese striped snake Elaphe quadrivirgata occasionally preys on eggs of M.reevesii (Fukada 1959; T. Yabe, pers. comm.). Hirai (2003) reported a case of predation on juvenile $M$. reevesii by the introduced bullfrog Lithobates catesbeianus in western Honshu. It is probable that feral dogs also sometimes prey on the turtle (Yasukawa, pers. obs.).Mauremys reevesii often emits strong-smelling volatile fluids from its axillary and inguinal musk glands.

Population Status. - In the 20th Century, several authors documented that $M$. reevesii was abundant in various areas of continental China (e.g., Sowerby 1925; Pope 1935; Liu and Hu 1940) and Taiwan (e.g., Mao 1971). However, judging from the fact that this turtle is disappearing from markets in continental China and the island of Taiwan (Chen et al. 2000; Lue et al. 1999; Lau and Shi 2000; Lau et al. 2000; Chen and Lue 2010; R.Aoki, pers.comm.), substantial population declines in these regions is highly likely, although no concrete population data are available. Ades et al. (2000) and Bhupathy et al. (2000) noted that $M$. reevesii was one of the commonest species seen in the food markets of China, Hong Kong, and Taiwan in the 1970s and early 1980s, but that they disappeared almost completely after the influx of turtles from other Asian countries. Recent surveys have revealed that this turtle is quite common on Kimmen Island, a small island off the coast of Taiwan (Chen et al. 2000; Lue et al. 1999), but may be rare on Taiwan itself (Chen et al. 2000; Chen and Lue 2010). In Hong Kong and other parts of China the species was previously considered a common species, but is now infrequently recorded (Lau et al. 2000; Lau and Shi 2000). In Japan, there is little fear of immediate extinction, since the turtle is often found in large numbers in various areas. Even so, it is highly likely that many populations have recently declined.

Threats to Survival. - The greatest threats to the survival of $M$. reevesii populations seem to be intense overexploitation for the food and pet trades, as well as habitat destruction caused by land development and various modifications to inland waters. Van Dijk (2011), in the current IUCN Red List assessment of this species, noted that $M$. reevesii has become increasingly subjected to intensive exploitation for food and medicine and the aquaculture industry, as well as being extensively impacted by habitat degradation and loss. Over the past 30 years the species has disappeared from at least half its original area of occurrence as a result of targeted collection.

Yabe (1993) reported that, at two small ponds in Gifu Prefecture of Japan, populations of this species, as well as M. japonica, declined dramatically and rapidly after development in and around their habitats.

Drugs derived from turtles have been used in Traditional Chinese Medicine since at least 2700 B.C., and M. reevesii has traditionally been one of the most popular species in the drug trade (Moll 1982). According to Moll (1982), the supply of turtles even back then was insufficient to satisfy the demand, leading to the importation of several non-Chinese species of turtles into Hong Kong to substitute for M.reevesii, implying that local stocks were already being depleted. Mao 
(1971) reported that the species had no economic value in Taiwan at the time, but shells from $M$. reevesii are now the most valuable in the high-volume Traditional Chinese Medicine market in Taiwan (Chen et al. 2009).

A large number of $M$. reevesii have been imported from continental China into Japan, the United States, and elsewhere for the pet trade since the early 1970s (Aoki 1990; Cheung and Dudgeon 2006). Such trade activities have severely impacted many Chinese populations of this species along with massive turtle farming efforts. The latter threatens wild stocks through replenishment of breeding stock from the wild and genetic pollution (Shi et al. 2008). In Japan, $M$. reevesii, apparently imported from China since the 1970s, are occasionally found in natural habitats mixed with populations (Yasukawa,pers.obs.) of animals from possible earlier introductions (Suzuki et al.2011). The introduced U.S.slider turtle (Trachemys scripta) may compete with the native $M$. reevesii for resources (Noda and Kamata 2004; N. Ohtaishi, pers. comm.). Although xenobiotic estrogens have not been demonstrated to be a threat to the species, immunological assay of baseline serum vitellogenin levels are established for $M$. reevesii, making it a useful bioindicator for exposure to such compounds (Tada et al. 2004).

Conservation Measures Taken. - In Japan, one pond on Mishima Island, inhabited by M.reevesii and M.japonica, was designated as a National Natural Monument in 1928, and is protected by the Japanese Government. No other effective conservation measures have been implemented for the Japanese populations of M.reevesii. In Taiwan, this turtle is protected as a rare and valuable species under the Wildlife Conservation Law of the national government (Chen et al. 2000). Also, the species is protected as Vulnerable by the National Law in South Korea (KACN 1989). The IUCN 2000 Red List (Hilton-Taylor 2000) assessed this turtle as Endangered, which was reaffirmed through it most recent re-assessment (van Dijk 2011). In 2005, M. reevesii (as Chinemys reevesii) was added to Appendix III of CITES by the People's Republic of China.

Although not oriented toward conservation, large-scale captive propagation of this species occurs in Hainan Province, China, indicating that there is a potential for captive breeding efforts (Shi and Parham 2001).

Conservation Measures Proposed. - Effective conservation of $M$. reevesi $i$ will require preservation of habitat consisting of a variety of terrestrial and aquatic microenvironments, in which individuals can make seasonal home range shifts for feeding, breeding, and hibernation (Kume et al. 2008; Tempaku et al. 2009; Haramura et al. 2010). Regulation of collecting and trade activities will also be essential. Detailed population studies are needed for each major population.

Captive Husbandry. - It is easy to keep M. reevesii, and some aquaria and pet keepers breed this species regularly. Fukada and Ishihara (1974) reported 15 cases of captive breeding of $M$. reevesii in outdoor pens in Kyoto, Japan. Acclimatization to conditions of outdoor captivity may take several years before reproduction occurs (Sachsse, 1975b).
Mauremys reevesii is one of the most abundant turtle species in Chinese turtle farms. Shi et al. (2008) estimated that there were over 2.7 million specimens in a subsample of officially recognized turtle farms (684 of 1499) that responded to a questionnaire asking about species and numbers of turtles held.

Current Research. - Populations in Kyoto, Gifu, and Chiba prefectures of Japan have recently been the focus of mark release-recapture studies by T. Yabe, Y. Kosuge, and several other researchers and students.

Acknowledgments. - We thank T. Yabe and R. Aoki for providing valuable information on the natural history of $M$. reevesii and its status in Chinese food markets, respectively. We also thank J.B. Iverson and T.-H. Chen for literature, and N. Kawazoe for color photographs.

\section{LITERATURE CITED}

Ades, G., Banks, C.B., Buhlmann, K.A., Chan, B., Chang, H.-C., Chen, T.-H., Crow, P., Haupt, H., Kan, R., Lai, J.-Y., LaU, M., Lin, H.-C., AND SHI, H. 2000. Turtle trade in Northeast Asia: regional summary (China, Hong Kong, and Taiwan). In: van Dijk, P.P., Stuart, B.L., and Rhodin, A.G.J. (Eds.). Asian Turtle Trade: Proceedings of a Workshop on Conservation and Trade of Freshwater Turtles and Tortoises in Asia. Chelonian Research Monographs No. 2, pp. 52-54.

Aoki, R. 1974. On the imported individuals of Chinemys reevesii. Herpetile Notes 12:122-124. (in Japanese)

AокI, R. 1990. Fresh water turtles of Japan. Natural History of Japan. 4:60-65. (in Japanese)

Barth, D., Bernhard, D., Guicking, D., Stock, M., and Fritz, U. 2003. Is Chinemys megalocephala Fang, 1934 a valid species? New insights based on mitochondrial DNA sequence data. Salamandra 38:233-244.

Barth, D., Bernhard, D., Fritzsch, G., and Fritz, U. 2004. The freshwater turtle genus Mauremys (Testudines, Geoemydidae) - a textbook example of an east-west disjunction or a taxonomic misconcept? Zoologica Scripta 33:213-221.

BICKHAM, J.W. AND CARR, J.L. 1983. Taxonomy and phylogeny of the higher categories of cryptodiran turtles based on a cladistic analysis of chromosomal data. Copeia 1983:918-932.

Bhupathy, S., Choudhury, B.C., Hanfee, F., Kalyar, Khan, S.M.M.H., Platt, S.G., AND RASHID, S.M.A. 2000. Turtle trade in South Asia: regional summary (Bangladesh, India, and Myanmar). In: van Dijk, P.P., Stuart, B.L., and Rhodin, A.G.J. (Eds.). Asian Turtle Trade: Proceedings of a Workshop on Conservation and Trade of Freshwater Turtles and Tortoises in Asia. Chelonian Research Monographs No. 2, pp. 101-105.

Buhlmann, K.A., Akre, T.S.B., Iverson, J.B., Karapatakis, D., MitTermeIER, R.A., GeOrges, A., Rhodin, A.G.J., vAN DiJK, P.P., AND GiBBons, J.W. 2009. A global analysis of tortoise and freshwater turtle distributions with identification of priority conservation areas. Chelonian Conservation and Biology 8:116-149.

Chang, T.-H. 1929. Notes on an apparently new or rarely known hardshell turtle from Fuchow. Contributions of the Biological Laboratory of the Science Society of China, Nanking 5(1):1-5.

Chen, T.-H. And Lue, K.-Y. 2010. Population status and distribution of freshwater turtles in Taiwan. Oryx 44:261-266.

Chen, T.-H., Chang, H.-C., And Kue, K.-Y. 2009. Unregulated trade in turtle shells for Chinese traditional medicine in East and Southeast 
Asia: the case of Taiwan. Chelonian Conservation and Biology 8:11-18.

Chen, T.-H., Lin, H.-C., And Chang, H.-C. 2000. Current status and utilization of chelonians in Taiwan. In: van Dijk, P.P., Stuart, B.L., and Rhodin,A.G.J.(Eds.). Asian Turtle Trade: Proceedings of a Workshop on Conservation and Trade of Freshwater Turtles and Tortoises in Asia. Chelonian Research Monographs No. 2, pp. 45-51.

Cheung, S.M. And Dudgeon, D. 2006. Quantifying the Asian turtle crisis: market surveys in southern China, 2000-2003. Aquatic Conservation: Marine and Freshwater Ecosystems 16:751-770.

CHow, M.-C. 1955. Notes on the remains of Chinemys from Hsiatsaohwan, Shihhung, northern Anhui. Acta Palaeontologica Sinica 3(1):69-72. (in Chinese with English abstract)

COOPER,J.E. 1961.Furthernotesonnon-indigenousturtles in Maryland. Herpetologica 17:209-210.

Crombie, R.I. and Pregill, G.K. 1999. A checklist of the herpetofauna of the Palau Islands (Republic of Belau), Oceania. Herpetological Monographs 13:29-80.

DALTON, R. 2003. Mock turtles. Nature 323:219-220.

Du,W.-G. ANDSHEN,J.-W.2007.Growth and sexual size dimorphismin the Chinese three-keeled pond turtle (Chinemys reevesii). Acta Herpetologica Sinica 11:42-47. (in Chinese with English abstract)

Du,W.-G. ANDZHENG, R.-Q. 2004. Egg survival and hatchling traits of the Chinese three-keeled pond turtle Chinemys reevesii incubated in differenthydric environments.ActaZoologicaSinica 50(1):133-136. (in Chinese with English abstract)

Du, W.-G. ZHENG, R.-Q. AND SHu, L. 2006. The influence of incubation temperature on morphology, locomotor performance, and cold tolerance of hatchling Chinese three-keeled pond turtles, Chinemys reevesii. Chelonian Conservation and Biology 5:294-299.

Du, W.-G., Hu, L.-J., Lu, J.-L., AND ZHU, L.-J. 2007. Effects of incubation temperature on embryonic development rate, sex ratio and post-hatching growth in the Chinese three-keeled pond turtle, Chinemys reevesii. Aquaculture 272:747-753.

DumérIL, A.M.C. AND DumérIL, A. 1851. Catalogue Méthodique de la Collection des Reptiles du Muséum d'Histoire Naturelle. Paris: Gide and Boudry, 224 pp.

ERnst, C.H. AND Barbour, R.W. 1989. Turtles of the World. Washington, DC: Smithsonian Institution Press, 313 pp.

ERnst, C.H. AND J.E. Lovich. 1990. A new species of Cuora (Reptilia: Testudines: Emydidae) from the Ryukyu Islands. Proceedings of the Biological Society Washington 103:26-34.

Ernst, C.H., Laemmerzahl, A.E., and Lovich, J.E. 2008. A morphological review of the Cuora flavomarginata complex (Testudines: Geoemydidae). Proceedings of the Biological Society Washington 121:391-397.

FANG, P.-W. 1934. Notes on some chelonians of China. Sinensia 4:145-199.

Feldman, C.R. And Parham, J.F. 2004. Molecular systematics of old world stripe-necked turtles (Testudines: Mauremys). Asiatic Herpetological Research 10:28-37.

FonG, J.J. AND CHEN, T.-H. 2010. DNA evidence for the hybridization of wild turtles in Taiwan: possible genetic pollution from trade animals. Conservation Genetics 11:2061-2066.

FonG, J.J., PARHaM, J.F., AND Fu, J. 2002. A reassessment of the distribution of Cuora flavomarginata Gray 1863 on mainland China. Russian Journal of Herpetology 9:9-14.

FUKADA,H.1959.Biological studies on the snakes.V.Foodhabits in the field. Bulletin of Kyoto Gakugei University, Series B (14):22-28.

FuKADA, H. 1965. Breeding habits of some Japanese reptiles (critical review). The Bulletin of Kyoto Gakuen University Series B (27):65-82.

FUKADA, H. AND ISHIHARA, S. 1974. Overwintering of hatchlings of the turtle Chinemys reevesii. Japanese Journal of Herpetology 5:45-48.

GafFney, E.S. and Meylan, P.A. 1988. A phylogeny of turtles. In: Benton, M.J. (Ed.). The Phylogeny and Classification of the Tetrapods, vol. 1, Amphibians, Reptiles, Birds. System Assoc. Spec. Vol. 35A. Oxford: Clarendon Press, pp. 157-219.

GibBons,J.W.ANDLovich,J.E. 1990.Sexual dimorphisminturtles with emphasis on the slider turtle (Trachemys scripta). Herpetological Monographs (4):1-29.

Gong, S., ShI, H., Fong, J.J., AND LAU, M. 2009. Recent records of freshwater turtles from Guangdong, China. Turtle and Tortoise Newsletter 13:24-27.

Gray, J.E. 1831. Synopsis Reptilium or Short Descriptions of the Species of Reptiles. Part 1. Cataphracta, Tortoises, Crocodiles, and Enaliosaurians. London: Treuttel, Wurtz \& Co., 85 pp.

GRAY, J.E. 1873. Damonia unicolor, a new species of water-tortoise from China, sent by Mr. Swinhoe. Annals and Magazine of Natural History (4)12:77-78.

HaRAmura, T., Y YMANE, M., AND Mori,A. 2010. Radiotelemetric study of movement patterns of lotic freshwater turtles during breeding and hibernation seasons. Journal of Freshwater Ecology 25:251-259.

Herrel, A., O'Reilly, J.C., AND Richmond, A.M. 2002. Evolution of bite performance in turtles. Journal of Evolutionary Biology 15:1083-1094.

Hikida, T. AND SuzuKi, D. 2010. The introduction of the Japanese populations of Chinemys reevesii estimated by the descriptions in the pharmacopias in Edo Era. Bulletin of the Herpetological Society of Japan 2010:31-36. (in Japanese)

Hilton-TAYloR, C. 2000.2000 IUCN Red List of Threatened Species. Gland and Cambridge: IUCN.

HIRAI, T. 2003. Reeves' pond turtle, Chinemys reevesii, eaten by exotic bullfrog, Rana catesbeiana. Bulletin of Kansai Organization for Nature Conservation 25:3-5. (in Japanese)

HIRAYAMA, R. 1984. Cladistic analysis of batagurine turtles (Batagurinae: Emydidae: Testudinoidea); a preliminary result. Studia Geologica Salmanticensia, volumen especial 1 (Studia Palaeocheloniologica I):141-157.

HiRayama, R. AND IsaJI, S. 2010. Additional turtle fossils from the Kiyokawa Formation of the Shimosa Group (Middle Pleistocene) at Sodegaru City, Chiba Prefecture, Japan. Journal of the Natural History Museum and Institute, Chiba 11:29-35. (in Japanese with English abstract)

Hirayama, R., KaneKo, N., AND OKaZAKI, H. 2007. Ocadia nipponica, a new species of aquatic turtle (Testudines: Testudinoidea: Geoemydidae) from the Middle Pleistocene of Chiba Prefecture, central Japan. Paleontological Research 11:1-19.

Honda,M.,Yasukana,Y.,Hirayama,R.,AndOta,H.2002.Phylogeny of the Eurasian freshwater turtles of the genus Mauremys Gray 1869 (Testudines), with special references to a close affinity of Mauremys japonica with Chinemys reevesii. Journal of Zoological Systematics and Evolutional Research 40:195-200.

Honda, M., FujI, R., AND DaIcho, K. 2007. Records of putative hybrids between two exotic turtles, Chinemys reevesii and Mauremys mutica, from Okinawajima Island of the Ryukyu Archipelago, Japan. Biological Magazine Okinawa (45):79-81. (in Japanese with English abstract)

IVERSON, J.B. 1992. A revised checklist with distribution maps of the turtles of the world. Richmond: Privately printed, $363 \mathrm{pp}$.

Iverson, J.B., Gotte, S., Lovich, J.E., AND ERnst, C.H. 1989. The validity of Chinemys megalocephala (Testudines: Batagurinae). Copeia 1989:494-498.

IsHIHARA, S. 1985. Temperature dependent sex determination of the freshwater turtle, Chinemys reevesii, in the terrarium. Japanese 
Journal of Herpetology 11:62. (Abstract in Japanese)

IsHIHARA, S. 1986. Temperature-dependent sex determination (TSD) in embryo after egg-laying by freshwater turtle, Chinemys reevesi. (Reptilia; Emydidae). Bulletin of Kyoto University of Education, Ser. B (74):27-38.

ISHIHARA, S. 1989. Temperature-dependent sex determination (TSD) in embryo after egg-laying by freshwater turtle, Chinemys reevesi. (Reptilia; Emydidae). Bulletin of Kyoto University of Education, Ser. B (74):27-38.

JiAng, Y., NIE, L.-W., Huang, Z.-F., Jing, W.-X., Wang, L., Liu, L., AND DAI, X.-T. 2011. Comparison of complete mitochondrial DNA control regions among five Asian freshwater turtle species and their phylogenetic relationships. Genetic and Molecular Research 10:1545-1557.

KACN (Korean Association for Conservation of Nature). 1989. Rare and Endangered Animals and Plants of Korea. Seoul: KACN, 165 pp. (in Korean)

Kaiser, H., Lopez Carvalho, V., Freed, P., and O'Shea, M. 2010. A widely traveled turtle: Mauremys reevesii (Testudines: Geoemydidae) in Timor-Leste. Herpetological Notes 3:93-96.

Kato, H., Kishida, K., Sasanami, T., Kansaku, N., Еtoh, H., AND ToRIYAMA, M. 2010. Detection of hybrid individuals between Mauremys japonica and Chinemys reevesii by RAPD. Biogeography 12:39-42.

KojIma, I. And Yamamoto-Yamazaki, K. 1987. Phylogenetic relationships among the three emydid turtles of Japan, Chinemys reevesii, Mauremys japonica and Mauremys mutica, as inferred by karyotypic analysis. Studies in Childhood Education, Seinan Gakuin University 14:47-51. (in Japanese)

Kosuge, Y., Ogano, H., and Hasegawa, M. 2003. Spatial distribution of the freshwater turtles along Koito River, Boso Peninsula. Journal of the Natural History Museum and Institute, Chiba, Special Issue 6:55-58. (in Japanese with English abstract)

Kume, K., Ikenoue, R., OKumura, K., Inamoto, Y., Kitagawa, T., Kubo, Y., AND HosoYa, K. 2008. Aquatic organisms of the paddy biotope, Kinki University. Memoirs of the Faculty of Agriculture, Kinki University 41:135-167. (in Japanese with English summary)

LAU, M. AND SHI, H. 2000. Conservation and trade of terrestrial and freshwater turtles and tortoises in the People's Republic of China. In: van Dijk, P.P., Stuart, B.L., and Rhodin, A.G.J. (Eds.). Asian Turtle Trade: Proceedings of a Workshop on Conservation and Trade of Freshwater Turtles and Tortoises in Asia. Chelonian Research Monographs No. 2, pp. 30-38.

Lau, M., Chan, B., Crow, P., and Ades, G. 2000. Trade and conservation of turtles and tortoises in the Hong Kong Special Administrative Region, People's Republic of China. In: van Dijk, P.P., Stuart, B.L., and Rhodin, A.G.J. (Eds.). Asian Turtle Trade: Proceedings of a Workshop on Conservation and Trade of Freshwater Turtles and Tortoises in Asia. Chelonian Research Monographs No. 2, pp. 39-44.

Li, H.-J. AND CUI, Y.-Y. 2011. Temperature effects on sex determination in Chinemys reevesii. Journal of Xinyang Normal University, Natural Science Edition 24:68-70. (in Chinese with English abstract)

LING, H. 1985. Sex determination by temperature for incubation in Chinemys reevesii. Acta Herpetologica Sinica 4(2):130. (in Chinese with English abstract)

Liu, C. AND Hu, S. 1940. Notes on growth of Geoclemys grangeri. Peking Natural History Bulletin 14:253-266.

Lovich, J.E., ERNST, C.H., AND GotTE, S.W. 1985. Geographic variation in the Asiatic turtle Chinemys reevesii (Gray), and the status of Geoclemys grangeri Schmidt. Journal of Herpetology 19:238-245.

Lovich, J.E. AND ERNST, C.H. 1989. Variation in the plastral formulae of selected turtles with comments on taxonomic utility. Copeia
1989:304-318.

LOVICH,J.E., GARSTKA, W.R., AND McCoy, C.J. 1990. The development and significance of melanism in the slider turtle. In: Gibbons, J.W. (Ed.), Life History and Ecology of the Slider Turtle. Washington, DC: Smithsonian Institution Press, pp. 233-254.

Lue, K.-Y., Tu, M.-C., and Shang, G. 1999. Field guide of Amphibians and Reptiles in Taiwan. Taipei: Society for Wildlife and Nature, 343 pp. (in Chinese)

Maenosono, T. And Toda, M. 2007. Distributions of amphibians and terrestrial reptiles in the Ryukyu Archipelago: A review of published records. Akamata (18):28-46. (in Japanese)

Mao, S.H. 1971. Turtles of Taiwan. Taipei: Commercial Press, 128 pp.

Masuno, T., Sasaki, T., and Yasukawa, Y. 1998. A record of the Reeves's pond turtle, Chinemys reevesii (Gray, 1831) (Testudines: Bataguridae), from Okinawa-jima Island, Ryukyu Archipelago. Biological Magazine, Okinawa 36:33-36. (in Japanese with English abstract)

McCoRD, W.P. 1997. Mauremys pritchardi, a new batagurid turtle from Myanmar and Yunnan, China. Chelonian Conservation and Biology 2:555-562.

McCord, W.P., Iverson, J.B., SinKs, P.Q., ANd SHAFFER, H.B. 2000. A new genus of geoemydid turtle from Asia. Hamadryad 25:20-24.

Moll, E.O. 1982. Freshwater turtles: the drug trade. Hamadryad 7:21-22.

NaKajima, M., NaKata, K., and Murakami, O. 2000. Distribution and age structure of the Japanese pond turtle and Reeves' pond turtle in a satoyama farm woodland area in Kyotanabe City, Kyoto Prefecture. Bulletin of Kansai Organization for Nature Conservation 22:91-103. (in Japanese)

Noda, H. AND KamatA, N. 2004. Relationships between population traits and food habits in aquatic turtles. Bulletin of the Herpetological Society of Japan 2004:102-113. (in Japanese)

OHNo, M. 1968. The herpetological fauna of the islands scattered in the Japan Sea. Journal of the Tokyo University of General Education 9:99-105. (in Japanese with English abstract)

OKada, S. AND OtA, H. 2003. Kusa-Game Chinemys reevesii. In: Kagoshima Red Data Book for Animals. Kagoshima: Kagoshima Prefectural Association of Environment and Technology, p. 98. (in Japanese)

OтА, H. 1991. Systematics and biogeography of terrestrial reptiles of Taiwan. In: Lin, Y.-S. and Chang, K.-H.(Eds.). Proceedings of the First International Symposium on Wildlife Conservation, ROC. Taipei: Council of Agriculture, pp. 47-112.

OтА, H. 2001. Order Testudines, suborder Lacertilia, and suborder Serpentes. In: Japan Wildlife Research Center (Ed.), Report of the BiodiversitySurvey-Distribution of Animalsin Japan(Amphibians and Reptiles). Fujiyoshida: Biodiversity Center, Ministry of Environment, pp. 207-225. (in Japanese)

Parham, J.F., Simison, W.B., KozaK, K.H.,Feldman, C.R., and Shi, H. 2001. New Chinese turtles: endangered or invalid? A reassessment of two species using mitochondrial DNA, allozyme electrophoresis and known-locality specimens. Animal Conservation 4:357-367.

PoPE,C.H.1935.NaturalHistory ofCentral Asia, Vol.10.The Reptiles of China. New York: American Museum of Natural History, 604 pp.

Pritchard, P.C.H. 1979. Encyclopedia of Turtles. Neptune, New Jersey: TFH Publications, 895 pp.

PRITCHARD,P.C.H.1994.Comments on Chinemyspalaeannamitica and certain other chelonian taxa based upon material from archeological sites. Chelonian Conservation and Biology 1:131-137.

SACHSSE,W.1975a.Chinemysreevesii var.unicolor und Clemmys bealei var.quadriocellata-Ausprägungen von Sexualdimorphismus der beiden "Nominatformen." Salamandra 11:20-26.

SACHSSE, W. 1975b. Jährliche nachzucht bei der chinesischen Dreik- 
ielschildkröte, Chinemys reevesii, unter teilweise geschützten freilandbedingungen in SW-Deutschland. Salamandra 11:7-9.

SAKA, M., TADA, N., AND KAMATA, Y. 2011. The annual ovarian cycle of the Reeves' pond turtle Chinemys reevesii (Reptilia: Geoemydidae) based on seasonal variations in the serum vitellogenin level and follicular growth. Current Herpetology 30:105-112.

Sasaki, T., Yasukawa, Y., Takahashi, K., Miura, S., Shedlock, A. M., AND OKADA, N. 2006. Extensive morphological convergence and rapid radiation in the evolutionary history of the family Geoemydidae (Old World pond turtles) revealed by SINE insertion analysis. Systematic Biology 55:912-927.

SCHLEGEL,H.1844.Abbildungen NeueroderUnvollständig Bekannter Amphibien,nach derNaturoderdemLebenEntworfen.Düsseldorf: Arnz, 141 pp.

ScHmid, K. P. 1925. New reptiles and a new salamander from China. American Museum Novitates 157:1-5.

SengoKu, S. 1979. Kusa-game (Chinemys reevesi) In: Sengoku, S. (Ed.). Amphibians and Reptiles in Color. Tokyo: Ieno-Hikari Kyokai, pp. 8-9. (in Japanese)

Shaffer, H.B., Meylan, P., and McKnight, M.L. 1997. Tests of turtle phylogeny: molecular, morphological, and paleontological approaches. Systematic Biology 46:235-268.

ShI, H. AND PARHAM, J.F. 2001. Preliminary observations of a large turtle farm in Hainan Province, People's Republic of China. Turtle and Tortoise Newsletter 3:4-6.

Shi, H., Parham, J.F., Zhiyong, F., Meiling, H., and Feng, Y. 2008. Evidence for the massive scale of turtle farming in China. Oryx 42:147-150.

Shibata, Y. 1967. Juvenile turtles sold in pet shops in Osaka. Nature Study 13:47-49. (in Japanese)

SмIтH, M. A. 1931. The Fauna of British India, including Ceylon and Burma. Reptilia and Amphibia, Vol. 1, Loricata and Testudines. Taylor and Francis, London. 185 pp.

SNIDER, A.T. AND Bowler, J.K. 1992. Longevity of reptiles and amphibians in North American collections. 2nd Ed. SSAR Herpetological Circular 21:1-40.

SowerBy, A.C. 1925. The Chinese terrapins. Chinese Journal Science and Arts 3:496-498.

SpINKs, P.Q., ShafFer, H.B., Iverson, J.B., AND McCord, W.P. 2004. Phylogenetic hypotheses for the turtle family Geoemydidae. Molecular Phylogenetics and Evolution 32:164-182.

SuzuKI, D., OTA, H., OH, H.-S., AND HIKIDA, T. 2011. Origin of Japanese populations of the Reeves' pond turtle, Mauremys reevesii (Reptilia: Geoemydidae), as inferred by a molecular approach. Chelonian Conservation and Biology 10(2):237-249.

SZYNDLAR, Z. 1991. Distributional records for turtles and lizards from North Korea. Herpetological Review 22:27.

Tada, N., SaKa, M., Ueda, Y., Hoshi, H., Uemura, T., and Kamata, Y. 2004. Comparative analyses of serum vitellogenin levels in male and female Reeve's pond turtles (Chinemys reevesii) by an immunological assay. Journal of Comparative Physiology B 174:13-20.

TAKENAKa, T. AND HaSEGaWA, M. 2001. Female-biased mortality and its consequences on adult sex ratio in the freshwater turtle Chinemys reevesii on an island. Current Herpetology 20:11-17.

TAO, H.-J. 1985. New fossil turtles, Chinemys pani n. sp.(Testudines) from the Chi-Ting formation (Pleistocene), Tainan District, Taiwan Island. Journal of Taiwan Museum 38(1):43-52.

TAO,H.-J. 1988. A new record of fossil turtle Chinemys reevesi (Gray) from Late Pleistocene, Taiwan Strait. Journal of Taiwan Museum 41(2):125-132.

Tempaku, M., Osawa, S., and Katsuno, T. 2009. Relationship between the faunistic composition of freshwater turtles and the habitat in Miura Peninsula. Journal of the Japanese Institute of Landscape
Architecture 72:547-552. (in Japanese with English abstract)

TurtleTaXonomy WorkingGroup[Bickham,J.W.,Iverson,J.B.,Parham, J.F.,PhIlipPen, H.-D., RhodIn,A.G.J.,ShafFer,H.B., SPINKs, P.Q., AND VAN DIJK, P.P.] 2007. An annotated list of modern turtle terminal taxa with comments on areas of taxonomic instability and recent change. In: Shaffer,H.B.,FitzSimmons, N.N., Georges,A., and Rhodin,A.G.J. (Eds.). Defining Turtle Diversity - Proceedings of Workshop on Genetics, Ethics, and Taxonomy of Freshwater Turtles and Tortoises, Chelonian Research Monographs No. 4, pp. 173-199.

VANDIJK,P.P. 2011.Mauremys reevesii.In: IUCN2011.IUCN Red List of Threatened Species. Version 2011.2. www.iucnredlist.org.

Wang, P.-C., MA, W., Lu, B., AND You, W.-H. 1995. Studies on the physiological ecology of incubation in Chinemys reevesii. Asiatic Herpetological Research 6:151-156.

Wink, M., Guicking, D., AND FRITZ, U. 2001. Molecular evidence for hybrid origin of Mauremys iversoni Pritchard and McCord, 1991, and Mauremys pritchardi McCord, 1997 (Reptilia: Testudines: Bataguridae. Zoologische Abhandlungen Staatliches Museum für Tierkunde Dresden 51(5):41-49.

Wu, P., ZHOU, K., AND YANG, Q., 1998. Evolution of hinged turtles in Bataguridae inferred from sequences of 12S rRNA gene. Chinese Journal of Applied and Environmental Biology 4:374-378. (in Chinese, with English abstract)

XIA, X., Wang, L., Nie, L., Huang, Z., JiAng, Y., Jing, W., AND Liu, L. 2011. Interspecific hybridization between Mauremys reevesii and Mauremys sinensis: Evidence from morphology andDNAsequence data. African Journal of Biotechnology 10:6716-6724.

YABE, T. 1993. Effect of the development of two wild ponds on the population of freshwater turtles. Bulletin of Kansai Organization for Nature Conservation 15:3-12. (in Japanese)

YABE,T.1994.PopulationstructureandmalemelanismintheReeves'turtle, Chinemys reevesii. Japanese Journal of Herpetology 15:131-137.

YABE, T. 2006. Current status of exotic turtles in Japan. Studies in Community Policy (8):47-57. (in Japanese)

YABE, T. 2009. Melanism in the Chinese three-keeled pond turtle Chinemys reevesii. Bulletin of the Herpetological Society of Japan 2009:187-190. (in Japanese)

Yasukawa, Y., Hirayama, R., and Hikida, T. 2001. Phylogenetic relationships of geoemydine turtles (Reptilia: Bataguridae). Current Herpetology 20:105-133.

You, W., Lu, B., AND WANG, P. 1993. The effect of ambient temperature and kinds of food on growth and digestion of juvenile turtles, Chinemys reevesii. Zoological Research 14:136-142. (in Chinese with English abstract)

ZHAO, E. AND AdLER, K. 1993. Herpetology of China, Contribution of Herpetology, vol. 10. Oxford: SSAR, 520 pp.

Zhu, X.-P., Du,H.-J.,ZHou,L.,LI, M.-Y., AND GuI, J.-F. 2005.Genetic diversity analysis of Chinese three-keeled pond turtle (Chinemys reevesii) by RAPD. Acta Hydrobiologica Sinica 29:171-176. (in Chinese with English abstract)

\section{Citation Format for this Account:}

Lovich, J.E., YasuKawa, Y., AND OTA, H. 2011. Mauremys reevesii (Gray 1831)-Reeves'Turtle, Chinese Three-keeled Pond Turtle. In: Rhodin, A.G.J., Pritchard, P.C.H., van Dijk, P.P., Saumure, R.A., Buhlmann, K.A., Iverson, J.B., and Mittermeier, R.A. (Eds.).Conservation Biology of FreshwaterTurtles and Tortoises: ACompilation Project of the IUCN/SSC Tortoise and Freshwater Turtle Specialist Group. Chelonian Research Monographs No. 5, pp. 050.1-050.10, doi:10.3854/crm.5.050.reevesii.v1.2011, http://www.iucn-tftsg.org/cbftt/. 